\title{
Rare occurrence of a transient isolated unilateral partial third nerve palsy after angioplasty
}

\author{
Apurva Vasavada, Pritesh Parekh, Navin Agrawal, Mahesh Vinchurkar
}

Department of Cardiovascular Sciences, Care Hospital, Surat, Gujarat, India

\section{Correspondence to} Dr Navin Agrawal,

drnavinagrawal@gmail.com

\section{DESCRIPTION}

We report a rare case of isolated unilateral partial oculomotor nerve palsy in an elderly woman a day after radial angioplasty presenting with diplopia and ptosis.

A 65 -year-old woman with diabetes and hypertension presented with the acute onset transient partial third cranial nerve palsy presenting as diplopia and ptosis after 1 day of undergoing a double vessel angioplasty which spontaneously improved after a day of its occurrence. The patient was in normal sinus rhythm and there was no echocardiographic evidence of any thrombus in the left-sided cardiac chambers. An ocular examination revealed ptosis with paresis of the muscles supplied by the oculomotor nerve with down and out cornea and mild mydriasis (figures 1-3). There was no other motor or sensory deficit suggestive of a cerebrovascular accident (CVA) or evidence of facial palsy or Horner's syndrome. MRI of the brain carried out subsequently was normal with no evidence of a CVA or cavernous sinus thrombosis.

The patient was managed conservatively. The symptoms improved spontaneously after 2 days and the patient was subsequently discharged on dual

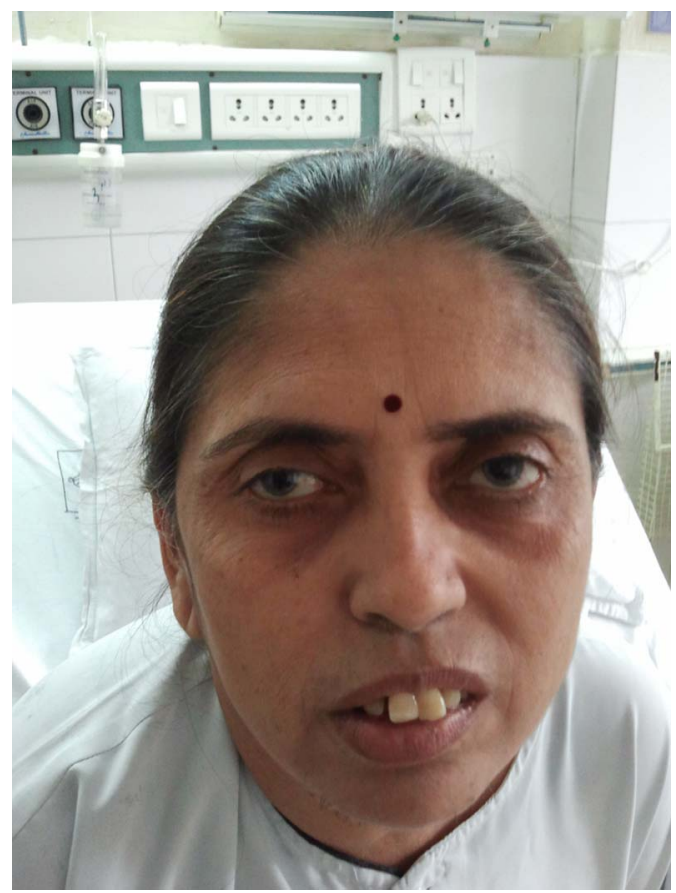

Figure 1 The patient on the second day of the procedure showing down and out cornea with ptosis in the right eye.

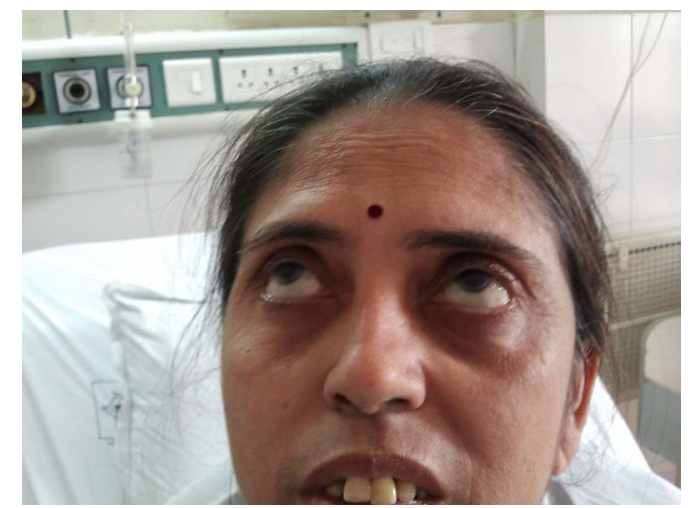

Figure 2 The patient showing preserved upward movement of the eye indicating preserved superior oblique nerve supplied by the fourth cranial nerve.

antiplatelet therapy as per the recommendations for patients after angioplasty.

The occurrence of oculomotor palsy after angioplasty has never been described before and the most plausible hypothesis for its occurrence could be a transient CVA caused by a lacunar infarct which was too small to be picked up on MRI involving the third nerve nuclei. Another hypothesis could be could be an oculomotor involvement as seen in patients with diabetes. ${ }^{1-3}$

It could also have been a transient inflammatory or immune response to contrast or an occulomotor palsy similar to that known to happen after neurosurgery. lastly it could have been just a coincidental occurrence of the illness after the procedure.

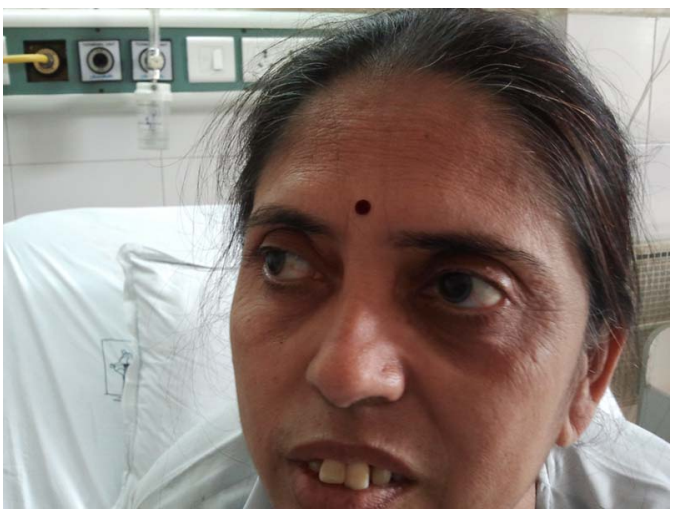

Figure 3 The patient showing preserved lateral movement of the eye indicating preserved lateral rectus nerve supplied by the sixth cranial nerve.
Parekh P, Agrawal N, et al. BMJ Case Rep Published

online: [please include Day

Month Year] doi:10.1136/

bcr-2013-201826 


\section{Learning points}

- Oculomotor nerve palsy can occur as a response to an angioplasty procedure but has never been reported after any percutaneous procedure before.

- The actual reason for its occurrence was not clear though there could be multiple hypotheses of which a microinfarct secondary to a carotid or aortic emboli caused by the dislodgement of an atheromatous plaque is the most plausible explanation.

- This case calls to attention an unknown mechanism of an adverse event which can occur after a successful angioplasty procedure which is an extremely important information for cardiologists considering the millions of procedures performed every year.
Contributors All authors contributed in patient care and the drafting of the manuscript.

Competing interests None.

Patient consent Obtained.

Provenance and peer review Not commissioned; externally peer reviewed.

\section{REFERENCES}

1 Asbury AK, Aldredge $H$, Hershberg $R$, et al. Oculomotor palsy in diabetes mellitus: a clinico-pathological study. Brain 1970;93:555-66.

2 Trobe JD. Isolated pupil-sparing third nerve palsy. Ophthalmology 1985;92:58-61.

3 Jacobson DM, McCanna TD, Layde PM. Risk factors for ischemic ocular motor nerve palsies. Arch Ophthalmol 1994;112:961-6.

Copyright 2013 BMJ Publishing Group. All rights reserved. For permission to reuse any of this content visit http://group.bmj.com/group/rights-licensing/permissions.

BMJ Case Report Fellows may re-use this article for personal use and teaching without any further permission.

Become a Fellow of BMJ Case Reports today and you can:

- Submit as many cases as you like

- Enjoy fast sympathetic peer review and rapid publication of accepted articles

- Access all the published articles

- Re-use any of the published material for personal use and teaching without further permission

For information on Institutional Fellowships contact consortiasales@bmjgroup.com

Visit casereports.bmj.com for more articles like this and to become a Fellow 